\title{
Coastal tourism development in Sinop as an emerging rural destination: A preliminary study from the residents' perspective
}

\author{
Desenvolvimento do turismo costeiro em Sinop como destino rural emergente: um estudo preliminar da \\ perspectiva dos residentes
}

\author{
Mustafa Daskin \\ Scool of Tourism, Amasya University, Amasya, Turkey, daskinmus@hotmail.com \\ Alpay Tiril \\ School of Tourism, Sinop University. Sinop, 57000, Turkey, alpaytiril@sinop.edu.tr
}

\author{
Alper Bozkurt \\ School of Tourism, Adana Aplarslan Türkeş Science and Technology University, Adana, Turkey, abozkurt@atu.edu.tr
}

\section{Abstract}

This study proposes to explore the economic, sociocultural, and environmental effects of coastal tourism development in a Turkish context. It adopts a quantitative approach and performed a random sampling technique. The survey data was collected from a sample of local people in Sinop/Turkey and total number of 252 utilizable questionnaires was gathered and analyzed through descriptive statistics. ANOVA test was also applied in order to compute the perceptional differences among demographical groups. The findings demonstrate that while majority of residents have positive perceptions in general, some agree with negative economic, sociocultural, and environmental effects of coastal tourism in the area. Specifically, they perceive that tourism raises the cost of products and services and as a result of an increase in living costs. ANOVA test shows that there were differences between educational groups in negative environmental impacts and age groups in positive economic impacts. In terms of sustainable coastal tourism, the present work procures further addition to tourism literature and also offers beneficial implications to industry practitioners.

Keywords: Coastal tourism, sustainability, tourism development, economic effect, sociocultural effect, environmental effect, Turkey.

\section{Resumo}

Este estudo pretende explorar os efeitos económicos, socioculturais e ambientais do desenvolvimento do turismo costeiro num contexto turco e adota uma abordagem quantitativa com uma técnica de amostragem aleatória. Os dados foram coletados de uma amostra de residentes locais em Sinop/Turquia num total de 252 questionários, que foram analisados através de estatística descritiva. O teste ANOVA também foi aplicado para calcular as diferenças percecionais entre os grupos demográficos. Os resultados demonstram que, embora a maioria dos moradores tenha perceções positivas em geral, alguns concordam que o turismo costeiro na área terá efeitos económicos, socioculturais e ambientais negativos. Especificamente, eles percebem que o turismo eleva o custo de produtos e serviços e terá como resultado um aumento no custo de vida. O teste ANOVA mostra que houve diferenças entre grupos educacionais em impactos ambientais negativos e faixas etárias em impactos económicos positivos. Em termos de turismo costeiro sustentável, o presente trabalho contribui para a literatura e também oferece implicações importantes para os profissionais da indústria.

Palavras-chave: Turismo costeiro, sustentabilidade, desenvolvimento turístico, efeito econômico, efeito sociocultural, efeito ambiental, Turquia.

\section{Introduction}

Tourism has an important place in national economies and social development. Tourism becomes an indispensable sector for the world economy. Tourism activities have become increasingly important in terms of balancing the levels of regional development, using sources effectively and increasing the number of tourists and tourism revenues. According to World Tourism Organization (WTO) (2018), the number of international tourist arrivals has risen by $6 \%$ to 1.4 billion in 2018 .

Normally, for a destination, the coastal sources play an important role to attract tourism investments and facilities. The reason for this is that the coastal surroundings generally have different types of natural resources together with cultural riches (Hengky, 2019). As such coral reefs, sandy beaches, birds, fish, marine mammals and other wildlife associated with cultural beauties such as historic sites, coastal towns, harbors, fishing fleets and etc. These natural sources are not endless and in contrast they are fragile and scarce, hence uncontrolled tourism development and tourist related activities may accelerate the extinction of them in the region (McLoughlin, Hanrahan, Duddy, and Duffy, 2018).

In this respect, Turkey has shown great improvement in tourism development and nearly the $90 \%$ of tourism demand is for coastal tourism. However, excessive movement of people to coastal areas especially in summer periods has resulted in destruction of natural resources and environmental pollution (Kişi, 2019; Kozak, Kozak, \& Kozak, 2006; 18-19). This situation showed that there was an urgent need to develop new strategies for sustainable tourism, therefore alternative tourism types became an agenda. Diversified tourism products and services constitutes alternative tourism concept that is different from mass tourism due to its organization and human resources involved in it. Thematic tourism and ecotourism that may be linked to religious, culinary and ethnographic heritage are the main sectors of alternative tourism type. 
While these developments happen, Sinop city as an emerging coastal tourism destination in the Black Sea region continues to host thousands of visitors in summer times. Sinop with its 50,000 inhabitants is one of Turkey's least populated provinces hosting Turkey's oldest population. Most people around $80 \%$ are engaged with agriculture, although its agricultural land is scarce and the industry has not developed. Also, fishing, animal farming and forestry generate the basic economy for Sinop province. Limited sources of the agricultural land around 200 thousand hectares forces Sinop province to compensate with marine and nature tourism and grow with the service industry products. Furthermore, the past research shows that Sinop is the most peaceful and happiest province in Turkey (Sinop Governorship, 2020) that is an attraction for holiday makers.

Specifically, Sinop is one of the unique places in the region which has unpolluted sandy beaches, resulting most of the visitors come for beaches in summer times. It is highly possible to see over crowdedness in the city and beaches where, the capacity is sometimes exceeded. Fortunately, there are various types of tourism potential in Sinop that may provide sociocultural and economic benefits to development. Rural tourism, ecotourism, historic tourism, culinary and ethnographic heritage tourism may be alternative types together with coastal tourism in Sinop.

The success of tourism within the destination relies heavily upon the residents' support for tourism development (Ayazlar \& Ayazlar, 2016; Yoon, Gursoy \& Chen, 2001). Therefore, it is an essential aspect of a sustainable tourism sector that the understanding of resident's attitudes and concerns towards tourism (Ap, 1992; Ap \& Crompton, 1993). McLoughlin, Hanrahan, and Duddy (2020) stressed that continuing monitoring is needed for economic viability of tourism, as it is an important factor of sustainability. In this regard, there is need for academic research in Sinop and other similar destinations in terms of understanding the current situation and create awareness for the necessary actions if needed. Otherwise, over-usage of resources without awareness can cause negative sociocultural and environmental demolish in the future. Against this backdrop, the current study aims to investigate the economic, sociocultural and environmental impacts of coastal tourism development in Sinop, Turkey. According to the literature review, the influence of coastal tourism has been widely concerned and surveyed by academia and the government. Rather than a theory-based approach, the current study adopted a preliminary deductive research approach and comes up with implications for better use of coastal resources in Sinop that becomes a place to the busy tourist activities in the summer. As a result, coastal areas face pressure over their utilization capacity. This pressure may cause environmental and ecological deterioration in the area. While these stay critical to investigate, as a contrast, the effects of coastal tourism activities from economic and sociocultural perspectives are also examined in the current study. So the current study will be a first preliminary study to shed light on the knowledge gap regarding coastal tourism development in Sinop.

\section{Literature review}

\subsection{Tourism in Sinop}

Sinop is located on Black Sea side of Turkey with its magnificent natural beauties and cultural sources. It is one of the oldest cities in the Anatolia region. It is possible to encounter the ruins of ancient civilizations in the city because many tribes tried to invade Sinop for dominance in the Black Sea and also settlement reasons (Turkey's Statistical Yearbook, 2017). Though Sinop possesses number of tourism resources, it could not reach the optimum tourist level. Specifically its long and unpolluted beaches continue to attract many people from other cities. Coastal tourism activities in summer reaches to maximum level and the population increases so much that causes traffic congestions, environmental issues and the capacity of the city is overloaded. The number of hotel establishments is also not enough to meet the demand in summer and homestay system has become a famous accommodation type in Sinop (Sinop Tourism, 2017). Recently, there are 10 hotels with more than 600 bed capacity in Sinop that are certified by the Tourism Ministry. In addition, there are flat type accommodations, public guest houses and pensions certified by the Sinop municipality to serve tourists. In this regard, Sinop Province Tourism Action Plan (2019-2022) has been prepared based on the "Turkey Tourism Strategy 2023". The Action Plan aims for systematic solutions to problems and diversification of sustainable tourism that can make a major contribution to the target point in the establishment of destination in order to increase its competitiveness (North Anatolian Development Agency, 2019).

\subsection{Sustainability of coastal tourism}

The common objectives of sustainable development are to expand the societies' economic welfare and provide more business occasions and to increase life quality (World Commission on Environment and Development, 1987). In order to succeed this aim, a balance should be met among social, economic and environmental requirements. First, an economic structure, which able to produce sustainable resources. Second the social system capable to simplify the source of technical knowledge. Third, the conserved coastal surroundings.

In this regard, academic research conducted by Nara, Mao, and Yen (2014) examined coastal tourism environmental administration policies in dealing with environmental effects and applying sustainable progress. They contend that those policies may be efficient in managing the environmental effect on applying sustainability of coastal tourism. Sustainable tourism is a critical element in the prosperous administration of natural resources in coastal regions (Brake and Addo, 2014). Previous research regarding 141 destinations based on coastal tourism (e.g., Brake and Addo, 2014; Elvarsdottir, 2013; Mavris, 2011; Nara et al., 2014) among 2011 and 2016 depicted that majority of the destinations are in need of government regulation and protected coastal surroundings (Hengky, 2014, 2016a). 
In the case of Turkey, where a significant majority of the population lives in coastal areas, various policies and administrative mechanisms are being developed on coastal areas. These policies are handled under four main headings, in accordance with the way people benefit from the coasts and marines; policies that emphasize tourism on the coasts, policies highlighting the transportation infrastructure and development on the coasts, policies that treat the coasts as part of the environment, and policies advocating the use of coasts primarily for public benefit (Ministry of Tourism, 2020).

Sustainable coastal tourism is one of the fastest growing tourist activities in the industry. In this sense, the coastal tourism activities can be well-managed using a systematic approach to coastal and marine administration that calls for strategies in managing coastal tourism sustainably. These strategies may include policy plan for coastal-marine management, infrastructure planning based on environmental care, technical knowledge and social learning and economic progress for promoting natural sources.

\subsection{Tourism impacts and residents' perceptions}

According to Social Exchange Theory, "people evaluate an exchange on the basis of the resulting benefits and costs of that exchange" (Pham and Kayat, 2011). Tourism creates both positive and negative impacts. The past research regarding tourism development has figured out the possible economic, social and environmental costs and benefits of coastal tourism. The most important contributions are increase in income level, employment, infrastructural progress, environmental consciousness and investment, cultural heritage reservation, and the contribution to sustainable social lives (Alrwajfah, Almeida-García and Cortés-Macías, 2019; Hançer and Mancı, 2017; Lee and Hsieh, 2016).

While the tourism industry is a driving force for both social and economic development, it also has potential to create sociocultural and environmental damage and other problems (Almeida-García, Peláez-Fernández, Balbuena-Vázquez, and Cortés-Macias, 2016; Smith, 2010; Wall \& Mathieson, 2006) such as biodiversity and habitat damage, pollution, climate change, loss of amenity, seasonality and sensitivity of demand, lack of community engagement and gains (e.g. Becken \& Moreno, 2009; Brunnschweiler, 2010; Jennings, 2004). Specifically, the advantages and disadvantages of coastal tourism development in new emerging regions make the situation more critical for sustainable tourism. Because handling this type of tourism in a sustainable form, it could even be more challenging when tourism is perceived as a driving force for a coastal area, which results in fast and excessive growth, excessive workforce migration, excessive use of natural environment, and high-spending tourist flows (Bramwell, 2004; Murray, 2007). Thus, these challenges create unsustainable outcomes unless the local institutions with effective authority, community involvement, and adequate management and planning (Ong, Storey, \& Minnery, 2011). According to WTO
(2005), this means tourism that "takes full account of its current and future economic, social and environmental impacts, addressing the needs of visitors, the industry, the environment and host communities".

Importantly, McLoughlin et al. $(2018,2020)$ applied the European Tourism Indicator System (ETIS) for their empirical studies conducted in Ireland. These studies demonstrate that the application of the ETIS ensures a beneficial instrument for monitoring the environmental and socioeconomic performance of destinations in terms of better sustainable management in the future.

In addition to this, the factors which may impact local peoples' perceptions about tourism impacts are documented in the past research. Mainly these factors can be examined under two groups such as intrinsic factors (demographics, interaction with tourists, distance from tourism zone, employment dependency on tourism, community attachment etc.) and extrinsic factors (type of tourism, tourists, stage of tourism development, seasonality etc.) (Alrwajfah et al., 2019; Gu and Ryan, 2008; Nunkoo and Gursoy, 2012). However, examining the influences of these factors is out of scope of the current study.

\subsection{Positive and negative economic impact of coastal tourism}

According to Stynes (1999), the common indicators of the economic development from tourism activities can be employment level, regional sales, and income level changes. Tourism activities develop local employment, income level, sales, and taxes but specifically this is more effective in entertainment, hotel, restaurant and retail sectors (Eagles, McCool \& Haynes, 2002). Wesley and Pforr (2010) stated that tourism is specifically welcomed due to huge consumption of accommodation and foods. Great amount of tourist spending improve the local residents' income level together with community tax levels (Kozhokulov, Chen, Yang, Issanova, Samarkhanov and Aliyeva, 2019; Murray, 2007). Parallel to this, new efforts and developments in a destination to meet the demands of tourists and visitors provide more trade and production opportunities which expand the other sectors as well. However, while all these happen, the negative impacts of coastal tourism economy are not generally taken into account in coastal tourism planning (Wesley \& Pforr, 2010). An empirical study conducted by Tosun (2002), reported that the tourism activities created more employment opportunities among residents but at the same time increased the cost of living. Meantime, tourism has increased tax levels and creates inflation in some coastal tourism regions (Andereck, 1995). The negative economic effects cannot be ignored as long as they are barriers to sustainable development. Importantly, the economic sustainability is extensively on the renewal agenda (Bell \& Morse, 2008).

\subsection{Positive and negative sociocultural impact of coastal tourism}

International Association for Impact Assessment (2003) defines social impacts as "the activities, programs or policies affect the 
society, communities, families or individuals directly or indirectly". Local people's approach towards tourism is influenced by different factors. First, the extent of reciprocal influence among tourists and local people, the society's view towards the industry, and may be others are effective to shape the attitude of local people (Murphy, 1985). Furthermore, in the coastal societies, sociocultural influences have been designated in "marine policy life" to improve the residents' welfare (HM Government, 2011). As a result, according to Gursoy, Jurowski, and Uysal (2002) and Royo and Ruiz (2009), if the destination and society administrators want to offer superior tourism activities and allure more tourists to improve residents' gains, they should provide community engagement for sustainable tourism development. According to Brunt and Courtney (1999), cultural identity, income, crime rate, employment rate, and transportation are mainly reflected by the effect of coastal tourism on local communities.

It is probable that tourists with various types of cultural identity may cause conflicts and/or crime. High number of tourist flow into a coastal area may raise the social population and creates over-crowdedness for both traffic and social activities. Additionally, new cultural interactions with tourists and residents commonly could make changes on the future generation's values, social life, and habits (Andereck, Valentine, Anshell, Knopf, \& Vogt, 2005). Specifically, the destinations which mostly dependent on coastal tourism are likely to encounter negative impacts by the community that makes the situation more difficult for local administrators in terms of sustainable tourism development. Luckily there are also positive influences of coastal tourism on the locals (Hengky, 2019). The development of public services is very important for local people and tourists as well, in this respect coastal tourism causes for buildings of new parks, better infrastructure, more cultural and recreational activities and so on. Moreover, Tosun (2002) reported that coastal tourism improves the public services and creates employment which in turn increases residents' welfare.

Dyer, Aberdeen, and Schuler (2003) stressed that "Local communities can mix with people from diverse backgrounds with different lifestyles, which through 'demonstration effect' that may lead to the development of improved lifestyles and practices by the tourists". For instance, in terms of sustainability, more traditional activities and better infrastructure lead to progress in local life that also results in better income, employment opportunities, education, and health care. In summary, the sociocultural effects of coastal tourism to a destination should be evaluated from both negative and positive sides. Remarkably, all effecting factors make serious changes on coastal city community and sustainability is needed to be followed carefully by local administrators.

2.6 Positive and negative environmental impact of coastal tourism

For a long time, the coastal areas are accepted as valuable natural sources that continue to attract more and more tourists in Europe (Vignetti, 2008). According to World Travel and
Tourism Council (2012), environmental development is a result of coastal tourism that is seen as locomotive for economic expansion. However, Creel (2003) and Hengky (2019) contended that coastal tourism developments have both negative and positive effects on the surroundings. According to Wilkinson and Salvat (2012), tourism interaction with environment causes a "big threat" that there is extinction in natural sources of coastal areas. According to Buckley (2011), there are three factors in order to evaluate whether the impact is positive or negative, that is; usage frequency of natural sources, magnitude of the source used, and tourism mobility rate. The effects of tourism are subject to tourist approach, tourism type, and tourist service quality (Medina-Munoz and Garcia-Falcon, 1998). Similarly, Altinay and Hussain (2005) reported that solid waste disposal, water quality, road traffic, natural vegetation are among the important environmental impact components in the Karpaz coastal area of Northern Cyprus. Moreover, Davenport and Davenport (2006) and Silva and Ghilardi-Lopez (2012) reported that tourism causes environmental problems like beach pollution, environmental health, natural source waste and so on. All these effects caused to squalling for better administration initiatives in coastal destinations, sustainability, and conservation (Lawrence, 2000; World Tourism Organization, 2004), such that the Integrated Coastal Zone Management and the United Nations program of Small Islands Developing states (SIDs) were established. An empirical study conducted by Hengky (2019) in Indonesia found a decline in biodiversity growth as a negative result of coastal tourism. As a result, it stays critical to continuously analyze the environmental impacts of coastal tourism activities that will provide environmental sustainability (Altinay and Hussain, 2005).

\section{Methodology}

\subsection{Sampling and data collection}

The current research purposes to investigate the conceptions of local people regarding the impact of tourism development in Sinop/Turkey. The study performed a random sampling technique by achieving a larger rate of the population in order to have credible, proper and objective data. The research team aimed to gather data from different occupational groups as much as possible. As an important criterion, the respondents are required to live in Sinop for more than 5 years. The reason for this was to collect more realistic data from the respondents who should have better experiences with the locational environment. A pilot test was applied with 10 respondents before distribution of the questionnaires in order to check the validity of the content. According to the pilot results, there was no drawback found to change the questionnaire content.

In order to achieve better response rate, the survey team spent effort to gather data on individual basis at the same day meetings. However, sometimes this could not be achieved and therefore the social media tools were applied when needed. Thus, in the current work, the most of the questionnaires were collected through face to face meetings with the voluntary 
participants. In some cases, the participants filled out and gave the questionnaires on the next day personally. In the present work, the employable number of questionnaires was 252 .

\subsection{Questionnaire development}

The scale for the present work adopted from Sanchéz-Cañizares, Nuñes-Tabales, and Fuentes-García (2014) in analyzing the effects of coastal tourism development from residents' perceptions in Sinop as an emerging tourism destination (see Appendix). The questionnaire composed of two main parts, regarding item questions and demographic profile of residents respectively. The first section consists of 34 questions which were divided into six sections. Sanchéz-Cañizares et al.'s (2014) study indicated that this scale had sufficient internal consistency. The second section includes five demographic items.

\subsection{Data analysis and procedure}

In order to analyze data set, Statistical Package for Social Sciences (SPSS) was performed. Firstly the reliability and validity tests were conducted. As a second step, the exploratory factor analysis was employed in assessing the dimensionality together with the convergent validity. After these, the descriptive statistics test was conducted to see average mean scores and finally the ANOVA was conducted to see if the level of education made any difference on perceptions.

\section{Analysis and results}

\subsection{Descriptive statistics}

Table 1 indicates that most of the respondents (58.7\%) in the current study were females. More than three quarters of the participants (78.9\%) were younger than 40 years old. Nearly the half of the participants possesses university degree (47.3\%). Respondents from different occupational groups attended in this study as shown in table 1 , such as $35.3 \%$ from public sector, $31.7 \%$ from private sector and so on. Finally, most of the participants (59.1\%) were composed of single marital status in the present research.

Table 1 - Sample profile $(n=252)$

\begin{tabular}{|l|c|c|}
\hline \multirow{2}{*}{ Demographic variable } & Sample composition & Percentage \\
\hline \multirow{3}{*}{ Gender } & Male & 41.3 \\
& Female & 58.7 \\
\hline \multirow{4}{*}{ Age } & $21-29$ years & 31.7 \\
& $30-39$ years & 47.2 \\
& O0-49 years & 12.7 \\
Education & Over 50 years & 8.3 \\
& Primary/secondary School & 52.8 \\
& Vocation/undergraduate School & 45.7 \\
& Masters/PhD & 1.6 \\
\hline \multirow{3}{*}{ Occupation } & Public sector employee & 35.3 \\
& Private sector employee & 31.7 \\
& Employer & 11.5 \\
& Farmer & 4.0 \\
& Student & 6.7 \\
& Unemployed & 2.8 \\
\hline \multirow{2}{*}{ Marital status } & Others & 8.0 \\
\hline
\end{tabular}

\subsection{Psychometric properties of the measure}

Reliability (Cronbach's Alpha) is a first-step statistical test for empirical studies. Table 2 depicts that each measures' reliability surpassed the threshold value of 0.70 as suggested by Nunnally (1978), shows that there is no random error and internal consistency is proper for constructs (Fornell \& Larcker, 1981). The Kaiser-Meyer-Olkin (KMO) measure of sampling adequacy was checked in order to assess if the variables' distributions was sufficient for performing further tests, as a consequence the variables surpassed the cut-off value of 0.50 as proposed by Field (2000). Thus, the data was applicable to perform exploratory factor analysis.
Table 2 - Reliability test score

\begin{tabular}{|l|c|c|}
\hline \multicolumn{1}{|c|}{ IMPACTS } & $\begin{array}{c}\text { Cronbach's } \\
\text { alpha }\end{array}$ & KMO \\
\hline Positive economic impacts & .77 & .864 \\
Positive socio-cultural impacts & .82 & .839 \\
Positive environmental impacts & .80 & .732 \\
Negative economic impacts & .70 & .512 \\
Negative social impacts & .81 & .840 \\
Negative environmental impacts & .73 & .712 \\
\hline
\end{tabular}

Table 3 demonstrates the factor loads of each construct that none of the items is under the threshold value of 0.50 as proposed by Barclay, Thompson, and Higgins (1995). The mean scores in table 3 indicate the perceptions of respondents towards each item scale and the standard deviations were also 
shown in table 3 . Again as depicted in table 3 , the results show that the residents have positive attitudes towards the positive economic impacts, positive socio-cultural impacts and positive environmental effects of coastal tourism development in Sinop. The average mean value of positive economic impact factor items was 4.23 , which means highly favorable in general. This translates as tourism benefits to the economy of residents in Sinop. The average mean value of positive socio-cultural impacts factor items was 4.26 , which is also highly favorable in general. This explains that tourism development in the area makes positive socio-cultural interactions between residents and visitors. Parallel to this, the average value for the positive environmental impacts factor items was 3.93 , means residents in general think tourism benefits to the renovation of the environment in the city.

Along with this, the present work purposed to explore the negative sights of tourism in the city because sustainability should be taken into account in the emerging tourism destinations, such that while tourism develops, it should not destroy the environment, ecological life, traditional life etc. Therefore, there is always a need for research to understand the current situation. Again as shown in table 3 , the residents in general are not much agree with the negative items towards economic, socio-cultural and environmental impacts of tourism development in Sinop. However, for the negative economic impacts, they are undecided with two statements, the rise in living costs (ECON18) and the rise in product prices and services (ECON19). The average mean value of negative economic impacts factor items was 3.36. When we look at the negative socio-cultural impacts items scale, we see that the residents are also undecided about some statements, such as, rise of traffic accidents ( $\mathrm{SCN} 22$ ), rise in robberies and vandalism ( $\mathrm{SCN} 23$ ), increase in illegal gambling (SCN25) and problems of coexistence between local residents and tourists (SCN28). The average mean value of the negative sociocultural impacts factor items was 2.64. These results show that most of the local people possess positive conceptions and give support for the development of tourism, however, some residents have no clear idea that tourism brings socio-cultural contribution. Finally, the average mean value of the negative environmental impacts factor items was 2.58 , which means that the residents in general are not agreed with the negative environmental impacts of tourism. However, they have negative perceptions related overcrowding of recreational areas (ENVN34). This shows a need for tourism planning for recreational areas.

Table 3 - Scale items, factor loads and mean scores

\begin{tabular}{|c|c|c|c|}
\hline Scale items & Factor loads & Standard deviation & Mean score \\
\hline \multicolumn{4}{|l|}{ Positive economic impacts } \\
\hline ECOP1 & 0.56 & 1.27 & 4,41 \\
\hline ECOP2 & 0.58 & 1.39 & 3,70 \\
\hline ECOP3 & 0.78 & 0.87 & 4,38 \\
\hline ECOP4 & 0.77 & 0.86 & 4,39 \\
\hline ECOP5 & 0.67 & 0.93 & 4,32 \\
\hline ECOP6 & 0.71 & 1.02 & 4,22 \\
\hline ECOP7 & 0.57 & 0.97 & 4,21 \\
\hline \multicolumn{4}{|l|}{ Positive socio-cultural impacts } \\
\hline SCP8 & 0.62 & 0.90 & 4,28 \\
\hline SCP9 & 0.68 & 0.83 & 4,34 \\
\hline SCP10 & 0.68 & 0.85 & 4,44 \\
\hline SCP11 & 0.52 & 0.92 & 4,17 \\
\hline SCP12 & 0.64 & 0.83 & 4,39 \\
\hline SCP13 & 0.50 & 1.03 & 3,95 \\
\hline \multicolumn{4}{|c|}{ Positive environmental impacts } \\
\hline ENVP14 & 0.59 & 1.13 & 3,84 \\
\hline ENVP15 & 0.56 & 1.23 & 3,96 \\
\hline ENVP16 & 0.65 & 1.16 & 4,02 \\
\hline ENVP17 & 0.69 & 1.15 & 3,90 \\
\hline \multicolumn{4}{|l|}{ Negative economic impacts } \\
\hline ECON18 & 0.75 & 1.12 & 3.94 \\
\hline ECON19 & 0.72 & 1.14 & 4.00 \\
\hline ECON20 & 0.77 & 1.44 & 2.70 \\
\hline ECON21 & 0.78 & 1.48 & 2.82 \\
\hline \multicolumn{4}{|c|}{ Negative socio-cultural impacts } \\
\hline SCN22 & 0.67 & 1.40 & 2,82 \\
\hline $\mathrm{SCN} 23$ & 0.57 & 1.37 & 2,65 \\
\hline SCN24 & 0.73 & 1.40 & 2,57 \\
\hline SCN25 & 0.75 & 1.43 & 2,64 \\
\hline SCN26 & 0.71 & 1.27 & 2,20 \\
\hline SCN27 & 0.63 & 1.28 & 2,30 \\
\hline SCN28 & 0.51 & 1.41 & 3,05 \\
\hline SCN29 & 0.85 & 1.31 & 2,40 \\
\hline $\mathrm{SCN} 30$ & 0.63 & 1.24 & 2,28 \\
\hline \multicolumn{4}{|c|}{ Negative environmental impacts } \\
\hline ENVN31 & 0.68 & 1.30 & 2,28 \\
\hline ENVN32 & 0.74 & 1.26 & 2,30 \\
\hline ENVN33 & 0.86 & 1.31 & 2,23 \\
\hline ENVN34 & 0.50 & 1.40 & 3,51 \\
\hline
\end{tabular}


In general, the findings of current study parallels to the past research (Almeida-García et al., 2016; Alrwajfah et al., 2019; Hengky, 2019; Kozak et al., 2006; Kozhokulov et al., 2019; McLoughlin et al., 2019; Smith, 2010).

Further, the present study employed one way ANOVA analysis in order to compute the perceptional differences among demographical groups as depicted in table 4 and 5 . There were no differences found among the demographical groups such as gender, occupation and marital status, so that is why they are not presented in a table. Based on the results, only differences were between educational groups in negative environmental impacts and age groups in positive economic impacts. Such that, as depicted in table 4 , the respondents who have vocational education had more negative attitudes towards environmental impacts when compared to primary school degree holders $(p>0.05)$. The respondents who have undergraduate degree had less negative attitudes towards environmental impacts when compared to vocational degree holders $(p>0.03)$.

As shown in the table 5 , the respondents between the age group of 21-29 possess less positive perceptions towards economic effects when compared to the age group of 40-49 ( $p$ $>0.05)$ and 50-over $(p>0.02)$. Similarly, the respondents between the age group of $30-39$ possess less positive perceptions towards economic influences when compared to the age group of $40-49(p>0.05)$ and 50 -over $(p>0.02)$. This finding depicts that the older people possess more positive attitudes towards the economic effects of coastal tourism development in Sinop.

Table 4 - ANOVA test in negative environmental impacts

\begin{tabular}{|c|c|c|c|c|c|c|}
\hline \multirow{2}{*}{ (I) Education } & \multirow{2}{*}{ (J) Education } & \multirow{2}{*}{ Mean Difference (I-J) } & \multirow{2}{*}{ Std. Error } & \multirow{2}{*}{ Sig. } & \multicolumn{2}{|c|}{ 95\% Confidence Interval } \\
\hline & & & & & Lower Bound & Upper Bound \\
\hline \multirow{4}{*}{ Primary } & High school &,- 16486 & ,16890 & 866 &,- 6290 & ,2993 \\
\hline & Vocational &,- 51638 & 19087 & 056 & $-1,0409$ & 0081 \\
\hline & Undergraduate & ,02746 & ,16597 & 1,000 &,- 4286 & ,4835 \\
\hline & Graduate &,- 35795 & ,50150 & ,953 & $-1,7361$ & 1,0202 \\
\hline \multirow{4}{*}{ High school } & Primary & ,16486 & ,16890 &, 866 &,- 2993 & 6290 \\
\hline & Vocational &,- 35153 & 19030 & ,349 &,- 8745 & ,1714 \\
\hline & Undergraduate & ,19232 &, 16532 & ,772 &,- 2620 & ,6466 \\
\hline & Graduate &,- 19310 & ,50129 & 995 & $-1,5707$ & 1,1845 \\
\hline \multirow{4}{*}{ Vocational } & Primary &, 51638 & 19087 &, 056 &,- 0081 & 1,0409 \\
\hline & High school & 35153 & 19030 & ,349 &,- 1714 & 8745 \\
\hline & Undergraduate & ,54385* & 18770 & 033 & 0280 & 1,0597 \\
\hline & Graduate & ,15843 & ,50911 & ,998 & $-1,2406$ & 1,5575 \\
\hline \multirow{4}{*}{ Undergraduate } & Primary &,- 02746 & 16597 & 1,000 &,- 4835 & ,4286 \\
\hline & High school &,- 19232 & ,16532 & ,772 &,- 6466 & ,2620 \\
\hline & Vocational &,$- 54385^{*}$ & ,18770 & ,033 & $-1,0597$ &,- 0280 \\
\hline & Graduate &,- 38542 & ,50031 & 939 & $-1,7603$ & 9894 \\
\hline \multirow{4}{*}{ Graduate } & Primary & 35795 & ,50150 & ,953 & $-1,0202$ & 1,7361 \\
\hline & High school & ,19310 & ,50129 & ,995 & $-1,1845$ & 1,5707 \\
\hline & Vocational &,- 15843 & ,50911 & ,998 & $-1,5575$ & 1,2406 \\
\hline & Undergraduate & ,38542 & ,50031 & 939 &,- 9894 & 1,7603 \\
\hline
\end{tabular}

Table 5 - ANOVA test in positive economic impacts

\begin{tabular}{|c|c|c|c|c|c|c|}
\hline \multirow{2}{*}{ (I) Age } & \multirow{2}{*}{ (J) Age } & \multirow{2}{*}{ Mean Difference (I-J) } & \multirow{2}{*}{ Std. Error } & \multirow{2}{*}{ Sig. } & \multicolumn{2}{|c|}{ 95\% Confidence Interval } \\
\hline & & & & & Lower Bound & Upper Bound \\
\hline \multirow{3}{*}{$21-29$} & $30-39$ &,- 02219 & 09768 & 996 &,- 2748 & ,2304 \\
\hline & $40-49$ &,$- 36786^{*}$ & 14131 & ,048 &,- 7334 &,- 0024 \\
\hline & 50 - over &,$- 48478^{*}$ & ,16565 & ,019 &,- 9132 &,- 0563 \\
\hline \multirow{3}{*}{$30-39$} & $21-29$ & 02219 & 09768 & ,996 &,- 2304 & ,2748 \\
\hline & $40-49$ &,- 34566 & ,13453 & 052 &,- 6936 & ,0023 \\
\hline & 50 and over &,$- 46259^{*}$ & 15991 & 021 &,- 8762 &,- 0490 \\
\hline \multirow{3}{*}{$40-49$} & $21-29$ & $36786^{*}$ & 14131 & ,048 & ,0024 & ,7334 \\
\hline & $30-39$ & ,34566 & 13453 & 052 &,- 0023 & 6936 \\
\hline & 50 and over &,- 11692 & 18973 & 927 &,- 6077 & ,3738 \\
\hline \multirow{3}{*}{50 ve ust } & $21-29$ & $48478^{*}$ & ,16565 & ,019 & ,0563 & ,9132 \\
\hline & $30-39$ & ,46259* & 15991 & 021 & 0490 & 8762 \\
\hline & $40-49$ & 11692 & 18973 & ,927 &,- 3738 & 6077 \\
\hline
\end{tabular}

Note: ${ }^{*}$ The mean difference is significant at the 0.05 level. 


\section{Conclusions}

In recent years, the places had natural, historical, cultural and archaeological values along with the coastal tourism potentials fastens the emergence and widespread of alternative tourism products all around the world. This is why the identification of alternative tourism potentials in the regions within the framework of sustainable tourism principles have become very important. Turkey as a case in point with its coastal tourism, has started to find its values and convert them to sustainable tourism potential. In this process, Sinop as Turkey's alternative coastal tourism location in the Gulf of Black Sea is developing at the forefront with its tourism values. However, in order to provide thriving tourism development plans for a touristic destination, it is very important to engage all stakeholders into the process and specifically the local peoples' perceptions and approaches regarding tourism development from sociocultural, economic and environmental aspects (Gursoy et al., 2002; Sanchéz-Cañizares et al., 2014). As a result, coordination and solidarity among the authorities (liable for tourism development plans) and local residents results in fewer conflicts of interest, otherwise may not be possible to provide quality tourism that produce gains and eliminates the negative effects of tourism (Gursoy et al., 2002).

In this regard, the current research purposed to explore the economic, socio-cultural and environmental impacts of tourism in Sinop as an emerging coastal tourism destination. The findings show that the majority of local people possess positive conceptions in general, but importantly some agreed with negative economic impacts; they perceive that tourism raises the cost of products and services and, as a result the living costs. This shows that the increasing number of tourist overflow to Sinop increases the demand for goods and services. This may create negative approach against tourists, therefore the local authorities should always keep a close eye on the private sector. There may be opportunists to increase prices.

Secondly, the residents seem undecided about some items of negative sociocultural impacts, such as the increase in travel accidents, robberies and vandalism, illegal gambling, and problems of co-existence among the residents and tourists. The process for coastal tourism development plan is tough and calls for long-term effort. Various groups from society such as municipality, civil organizations, educational institutions, and host community representatives should come together and spend time to regulate tourism. On the other hand, effects of tourist movements in a destination should not be evaluated from local community point of view only. Local community's approach and behaviors towards visitors make sense for a healthy sociocultural interaction with tourism facilities. Tourist flow to a destination for holiday is perpetual and they come with their personal values and cultures that likely to create incompatibility with residents' values unless handled by local stakeholders. In this respect, socialization steps between host community and tourists stays critical; sociocultural events may be arranged by the local stakeholders in order to attract local people and visitors to come together. Sociocultural facilities may be beneficial tools to communicate cultural values and even sensibilities of the local people. But it should not be forgotten that this process is a reciprocal and the local authorities should take this into account in order to constitute better connection among both parties. Moreover, tourist flows to Sinop in summer from abroad and neighbouring cities mostly exceed the carrying capacity in the area that calls for more catering services, as well as new-designed infrastructure and transportations for sustainable coastal tourism. Specially, the food and beverage sector should expand under the control of municipality, otherwise these demands could be met by unprofessional people and this may result in negative destination image in the future. Therefore, achieving sustainable coastal tourism in Sinop mostly subjected to the stakeholders' efforts in preparing a comprehensive planning to eliminate the negative sociocultural impacts of tourism in Sinop destination.

Thirdly, the residents perceive that tourism makes overcrowding of recreational areas in Sinop. The recreational activities and new hotel constructions result in more pollution as well; poorer natural values, drain water that fouls sea, depletion of flora and fauna and so on. While the local people get the gains of tourism development, on the other hand, they should be full aware of the negative impacts or costs to the environment. For this reason, tourism boards may be established where the environmental issues are analyzed and discussed, as well as the public awareness is aimed.

Like other empirical research studies, the present work also has some limitations. As such, this study lacks qualitative dimension that may be useful to learn more insights into the perceptions. So, future studies needed to conduct in-depth interviews and observations. Moreover, the current study does not examine the impacts of intrinsic and extrinsic factors on perceptions. Thus, a future research study can be conducted to examine the effects of some intrinsic and extrinsic factors. Also, examining the perceptions of tourists and enterprises in Sinop may be critical for sustainable tourism development in near future.

\section{References}

Almeida-García, F., Peláez-Fernández, M. Á., Balbuena-Vázquez, A. \& Cortés-Macias, R. (2016). Residents' perceptions of tourism development in Benalmádena (Spain). Tourism Management, 54, 259-274.

Alrwajfah, M.M., Almeida-García, F. \& Cortés-Macías, R. (2019). Residents' Perceptions and Satisfaction toward Tourism Development: A Case Study of Petra Region, Jordan. Sustainability, 11, 1-19.

Altinay, M. \& Hussain, K. (2005). Sustainable tourism development: a case study of North Cyprus. International Journal of Contemporary Hospitality Management, 17(3), 272-280.

Andereck, K. L. (1995). Environmental Consequences of Tourism: A Review of Recent Research. In Linking Tourism, the Environment, and Sustainability. Annual Meeting of the National Recreation and Park Association, pp. 77-81, General Technical Report No. INT-GTR-323.

Andereck, K.L., Valentine, K.M., Anshell, M., Knopf, R.C. \& Vogt, C.A. (2005). Residents' perceptions of community tourism impacts. Annals of Tourism Research, 32(4), 1056-1076. 
Ap, J. (1992). Residents' perceptions on tourism impacts. Annals of Tourism Research, 19(4), 665-690.

Ap, J. \& Crompton, J. L. (1993). Residents' Strategies for Responding to Tourism Impacts. Journal of Travel Research, 3(1), 47-50.

Ayazlar, R.A. \& Ayazlar, G. (2016). Residents' tourism support behaviour: the role of sustainable tourism attitude. Enlightening Tourism. A Pathmaking Journal, 6(2), 124-149.

Barclay, D.W., Thompson, R. \& Higgins, C. (1995). The partial least squares (PLS) approach to causal modeling: Personal computer adoption and use an illustration. Technology Studies, 2(2), 285-309.

Becken, S. \& Moreno, A. (2009). A climate change assessment methodology for coastal tourism. Journal of Sustainable Tourism, 17(4), 473-488.

Bell, S. \& Morse, S. (2008). Sustainability indicators measuring the immeasurable? London: Earthscan.

Brake, W. \& Addo, E. (2014). Tourism and Fracking in Western Newfoundland: Interests and Anxieties of Coastal Communities and Companies in the Context of Sustainable Tourism. International Journal of Marine Science, 4(2), 16-41.

Bramwell, B. (2004). Coastal Mass Tourism: Diversification and Sustainable Development in Southern Europe. Channel View Publications, Clevedon.

Brunnschweiler, J. (2010). The Shark Marine Reserve: a marine tourism project in Fiji involving local communities. Journal of Sustainable Tourism, 18(1), 29-42.

Brunt, P. \& Courtney, P. (1999). Host Perceptions of Socio-Cultural Impacts. Annals of Tourism Research, 26(3), 493-515.

Buckley, R. (2012). Sustainable Tourism: Research and reality. Annals of Tourism Research. 39(2), 528-546.

Creel L. (2003). Ripple effects: Population and coastal regions. Population Reference Bureau. USAID MEASURE communication project.

Davenport, J. \& Davenport, J.L. (2006). The impact of tourism and personal leisure transport on coastal environments: A review. Estuarine Coastal and Shelf Science, 67, 280-292.

Dyer, P., Aberdeen, L. \& Schuler, S. (2003). Tourism Impacts on an Australian Indigenous Community: a Djabugay Case Study. Tourism Management, 24(1), 83-95.

Eagles, P. F. J., McCool, S. F. \& Haynes, C. F. (2002). Sustainable tourism in protected areas: Guidelines for planning and management. Gland, Switzerland: International Union for the Conservation of Nature.

Elvarsdottir, H.S. (2013). An Approach towards sustainable tourism management: nature-based tourism in Nuup Kangertua, Greenland. Coastal and Marine Management, (Thesis), Greenland.

Field, A. (2000). Discovering Statistics using SPSS for Windows. London, Thousand Oaks, New Delhi: Sage publications.

Fornell, C. \& Larcker, D.F. (1981). Evaluating structural equation models with unobservable and measurement error. Journal of Marketing Research, 18(1), 39-50.

Gu, H. \& Ryan, C. (2008). Place attachment, identity and community impacts of tourism: The case of a Beijing hutong. Tourism Management, 29, 637-647.

Gursoy, D., Jurowski, C. \& Uysal, M. (2002). Resident attitudes: A Structural Modeling Approach. Annals of Tourism Research, 29(1), 79-105.

Hançer, Ş. \& Mancı, A.R. (2017). A Research on the Determination of Residents' Perception About Tourism in Diyarbakir. Journal of Tourism and Gastronomy Studies, 5/4, 70-91.

Hengky, S.H. (2014). Investigated Sustainable Coastal Tourism in Samudra Baru and Tanjung Pakis Beach, Karawang, West Java, Indonesia. Environmental Management and Sustainable Development, 3(1), 233-242.

Hengky, S.H. (2016a). Co-management: Valuating Social Communication of Sustainable Coastal Tourism, in Indonesia. International Journal of Marine Science, 6(46), 1-10.
Hengky, S.H. (2019). Challanges sustainable coastal tourism on Panjang Island. Journal of Aquaculture \& Marine Biology, 8(5),180-184.

HM Government. (2011). Marine Policy Statement. London: HMSO. Available online at http://www.defra.gov.uk/environment/marine/protect/planning/.

International Association for Impact Assessment. (2003). Why have Principles for Social Impact Assessment? Special Publication Series No. 2. Available at www.iaia.org/publicdocuments/specialpublications/sp2.pdf.

Jennings, S. (2004). Coastal Tourism and Shoreline Management. Annals of Tourism Research, 31(4), 899-922.

Kişi, N. (2019). A Strategic Approach to Sustainable Tourism Development Using the A'WOT Hybrid Method:A Case Study of Zonguldak, Turkey. Sustainability, 11, 1-19.

Kozak, N., Kozak A.M. \& Kozak, M. (2006). Genel Turizm - ilkeler ve Kavramlar (in Turkish). Detay Yayıncllık, Ankara.

Kozhokulov, S., Chen, X., Yang, D., Issanova, G., Samarkhanov, K. \& Aliyeva, S. (2019). Assessment of Tourism Impact on the SocioEconomic Spheres of the Issyk-Kul Region (Kyrgyzstan). Sustainability, 11, 1-18.

Lawrence, D.P. (2000). Planning theories and environmental impact assessment. Environmental Impact Assessment Review, 20, 607-625.

Lee, T.H. \& Hsieh, H.P. (2016). Indicators of sustainable tourism: A case study from a Taiwan's wetland. Ecological Indicators, 67, 779-787.

Mavris, C. (2011). Sustainable Environmental Tourism and Insular Coastal Area Risk Management in Cyprus and the Mediterranean. Journal of Coastal Research, 61, 317-327.

McLoughlin, E., Hanrahan, J, Duddy, A. \& Duffy, S. (2018). European Tourism Indicator System for Sustainable Destination Management in County Donegal Ireland. European Journal of Tourism Research, 20, 7891.

McLoughlin, E., Hanrahan, J. \& Duddy, A.M. (2020). Application of the European tourism indicator system (ETIS) for sustainable destination management. Lessons from County Clare, Ireland. International Journal of Culture, Tourism and Hospitality Research, 14(2), 273-294.

Medina-Munoz, D. \& Garcia-Falcon, J. (1998). A strategic planning methodology for sustainability in islands. 7th conference of the Greening industry network. Rome, Italy.

Murphy, P. E. (1985). Tourism: A Community Approach. New York: Routledge.

Murray, G. (2007). Constructing Paradise: The Impacts of Big Tourism in the Mexican Coastal Zone. Coastal Management, 35(2-3), 339-355.

Nara, P., Mao, G. \& Yen, T. (2014). Applying Environmental Management Policy for Sustainable Development of Coastal Tourism in Thailand. International Journal of Environmental Protection and Policy, 1, 19-23.

North Anatolian Development Agency. (2019). Sinop Province Tourism Action Plan (2019-2022). Available at https://www.kuzka.gov.tr/planlama.asp?P=57\&Planlama=sinop-ilturizm-eylem-plani.

Nunkoo, R. \& Gursoy, D. (2012). Residents' support for tourism: An identity perspective. Annals of Tourism Research, 39, 243-268.

Nunnally, J.C. (1978). Psychometric theory (2nd Ed.). New York: McGraw-Hill Book Company.

Ong, L.T.J., Storey, D. \& Minnery, J. (2011). Beyond the beach: Balancing environmental and socio-cultural sustainability in Boracay, the Philippines. Tourism Geographies, 13(4), 549-569.

Pham, L. \& Kayat, K. (2011). Residents' Perceptions of Tourism Impact and Their Support for Tourism Development: The Case Study of Cuc Phuong National Park, Ninh Binh Province, Vietnam. European Journal of Tourism Research, 4, 123-146.

Ritchie, B. \& Inkari, M. (2006). Host community attitudes toward tourism and cultural tourism development: the case of the Lewes District, Southern England. International Journal of Tourism Research, 8(11), 27-44. 
Royo, M. \& Ruiz, M. E. (2009). Actitud del residente hacia el turismo y el visitante: factores determinantes en el turismo y excursionismo ruralcultural. Cuadernos de Turismo, 23, 217-236.

Sanchéz-Cañizares, S., Nuñes-Tabales, J. \& Fuentes-García, F. (2014). Tourism \& Management Studies, 10(1), 87-96.

Silva, J.N. \& Ghilardi-Lopez, N.P. (2012) Indicators of the impacts of tourism on hard-bottom benthic communities of Ilha do Cardoso State Park (Cananeia) and Sonho Beach (Itanhaem), two southern coastal areas of Sao Paulo State (Brazil). Ocean \& Coastal Management, 58, 1-8.

Sinop Governorship. (2020). Available at http://www.sinop.gov.tr/ekonomi. Accessed on May 2020.

Sinop Tourism. (2017). Available at http://www.sinopkulturturizm.gov.tr/. Accessed on August 2017.

Smith, R.A. (2010). Achieving successful development planning. In R.A. Smith \& J. Siguaw (Eds.), Strategic hospitality leadership: The Asian initiative (pp. 19-38). New York: JohnWiley \& Sons.

Stynes, D. J. (1999). Approaches to estimating the economic impacts of tourism; some examples. East Lansing, MI: Department of Park, Recreation and Tourism Resources, Michigan State University.

Tosun, C. (2002). Host perceptions of impacts. Annals of Tourism Research, 29(1), 231-253.

Ministry of Tourism. (2020). Available at https://www.ktb.gov.tr/TR96268/turizm.html.

Turkey's Statistical Yearbook. (2017). Province Indicators. Available at http://tuik.gov.tr/. Accesses on August 2017.

Vignetti, S. (2008). The impact of tourism on coastal areas: regional development aspects. Brussels: European Parliament.

Wall, G. \& Mathieson, A. (2006). Tourism: Change, impacts and opportunities. Harlow: Pearson Education.

Wesley, A. \& Pforr, C. (2009). Historical dimensions of coastal tourism. In R. Dowling \& C. Pforr (Eds.), Coastal tourism development (pp. 1529). New York: Cognizant Communication Corporation.

Wilkinson, C. \& Salvat, B.M. (2012). Coastal resource degradation in the tropics: Does the tragedy of the commons apply for coral reefs, mangrove forests and sea grass beds. Marine Pollution Bulletin, 64(6), 1096-1105.

World Commission on Environment \& Development. (1987). Our common future. Oxford University Press, Oxford.UK.

World Tourism Organization. (2004, 2005). Making Tourism More Sustainable: a guide for policymakers. UNEP and World Tourism Organization, Madrid

World Tourism Organization. (2018). Tourism Highlights 2018 Edition. Available at https://www.eunwto.org/doi/pdf/10.18111/9789284419876.

World Travel \& Tourism Council. (2012). Economic Impact of Tourism. Available at https://www.wttc.org/research/economicresearch/economic-impact-analysis/

Yoon, Y., Gursoy, D. \& Chen, J. S. (2001). Validating a tourism development theory with structural equation modeling. Tourism Management, 22(4), 363-372.

Received: 15.02 .2020

Revisions required: 14.03 .2020

Accepted: 10.04 .2020 